12. Foresta $\mathrm{C}$ et al. Blood levels, apoptosis, and homing of the endothelial progenitor cells afterskin burns and escharectomy. J Trauma. 2011; 70: 459-465.

13. Wolf FI, Trapani V, Simonacci M, Ferre S, Maier JA Magnesium deficiency and endothelial dysfunction: is oxidative stress involved? Magnes Res. 2008; 21: 58-64.

14. Spasov AA, Iejica IN, Haritonova MV, Jeltova AA, Ozerov AA. Vliyanie solei magniya na koncentraciu endotelial'noi NO-sintazi v usloviyah alimentarnogo deficit magniya [Effect of magnesium salts at concentrations of endothelial NO- synthase in terms of nutritional magnesium deficiency]. Vestnik Orenburgskogo gosudarstvennogo universiteta [Bulletin of the Orenburg State University]. 2011; 15: 156-157.
15. Kawasaki K, Eiji K, Yoshitsugu C, Satou M, Hiroshi T, Hikaru K, Satoru T, Noriomi M, Ikuo K. Magnesium sulfate may ameliorate oxidativestress through increasing glutathione synthesis gene in preeclampsia. Placenta. 2016; 46: 119.

16. Andreev AV, Gromova OA, Fedotova EL, Burtsev EM. Vlianie preparata Magne B6 na cerebrovaskularnuiu reaktivnost' $u$ detei $s$ sindromomdeficita vnimaniya $v$ zavisimosti ot soderjaniya magniya $v$ organizme [The impact with attention deficit disorder drug Magne B6 on cerebrovascular reactivity in children, depending on the content of magnesium in the body]. Klin. Farmakologiya i terapiya [Clinical Pharmacology and Therapeutics]. 2000; 5: 31-34.

\title{
ADAPTATION OF THE MEDICAL ACHIEVEMENT SELF-EFFICACY SCALE (MASS) INTO TURKISH
}

TURAN SEVGI, MSc, PhD, Associate Professor of Medical Education, Hacettepe University Faculty of Medicine, Department of Medical Education and Informatics, Sihhiye Campus, Turkey, 06100, Ankara, e-mail: sturan@hacettepe.edu.tr ELCIN MELIH, MD, MSC, CHSE, Professor of Medical Education, Hacettepe University Faculty of Medicine, Department of Medical Education and Informatics, Sihhiye Campus, Turkey, 06100, Ankara, DERESE ANSELME, MD, PhD, Associate Professor of Family Medicine and Medical Education, Ghent University Faculty of Medicine, Department of Family Medicine and Primary Health Care, De Pintelaan 185, 6K3, 9000, Ghent, Belgium

Abstract. Aim Curriculum innovators are eager to evaluate the overall effects of curriculum changes. In a Belgian-Turkish collaboration we developed a scale, for content validity based on the competency frameworks of CanMEDs and The Five Star Doctor, to measure self-efficacy changes in undergraduate medical students. In this study, the reliability and construct validity of Medical Achievement Self-efficacy Scale (MASS) among Turkish medical students were examined. Material and methods. The MASS contains 18 items, to be rated on a five-point Likert scale. The study was conducted with undergraduate medical students at Hacettepe University $(n=547)$. The Turkish form of the scale was examined for content validity by five experts. Cronbach's alpha was calculated for reliability of the scale. Item-total correlation was calculated and the scores of lowly and highly performing groups were compared by means of a t-test. Exploratory factor analysis was conducted to determine the construct validity. Results and discussion. The content validity of the Turkish MASS was considered appropriate. The reliability of the scale was high (Cronbach's a=0,89). Item-total correlation coefficients of the Turkish MASS ranged from 0,53 to 0,70. Lower and upper score groups were compared as an indicator of the discriminant validity. All items discriminated significantly between lowly and highly performing students. Factor analysis showed that the scale has a one factor structure which explains $37,89 \%$ of the variance. Factor loadings ranged from 0,56 to 0,73 . Conclusions. The study showed the reliability and delivered evidence about the construct validity of the Turkish adaptation of the MASS.

Key words: academic self-efficacy, medical students, scale development.

For reference: Turan S, Elcin M, Derese A. Adaptation of the Medical Achievement Self-efficacy Scale (MASS) into Turkish. The Bulletin of Contemporary Clinical Medicine. 2017; 10 (2): 53-57. DOI: 10.20969/VSKM.2017.10(2).53-57.

\section{АДАПТАЦИЯ ШКАЛЫ САМОЭФФЕКТИВНОСТИ МЕДИЦИНСКИХ ДОСТИЖЕНИЙ (MАSS) ДЛЯ ТУРЦИИ}

ТУРАН СЕВГИ, магистр наук, доцент кафедры медицинского образования и информатики медицинского факультета Университета Хачеттепе, кампус Сиххийе, Турция, 06100, Анкара, e-mail: sturan@hacettepe.edu.tr

эльчин МЕЛИХ, магистр наук, сертифицированный педагог в области симуляционной медицины, профессор кафедры медицинского образования и информатики медицинского факультета Университета Хачеттепе, кампус Сиххийе, Турция, 06100, Анкара

ДЕРЕСЕ АНСЕЛМЕ, докт. меД. наук, профессор кафедры медицинского образования и информатики медицинского факультета Университета Хачеттепе, кампус Сиххийе, Турция, 06100, Анкара

Реферат. Цель. Новаторы образовательного процесса стремятся оценить общие последствия изменений в учебной программе. В бельгийско-турецком сотрудничестве мы разработали шкалу валидности содержания для измерения изменений самоэффективности студентов-медиков на основе квалификационных рамок CanMEDs и The Five Star Doctor. В данном исследовании была проверена достоверность и обоснованность шкалы самоэфффективности медицинских достижений (MASS) среди турецких студентов-медиков. Материал и методы. MASS содержит 18 пунктов, которые должны быть оценены по пятибалльной шкале Ликерта. Исследование проводилось с участием студентов-медиков в Университете Хачеттепе ( $n=547)$. Турецкая форма шкалы была проверена пятью экспертами на достоверность. Альфа ( $\alpha$ ) Кронбаха рассчитывалась для вычисления надежности. Выводили итоговую корреляцию по всем пунктам, а баллы групп с низкой и высокой эффективностью сравнивали 
с помощью t-критерия Стьюдента. Оценка фракторной структуры была проведена для определения конструктивной достоверности. Результаты и их обсуждение. Валидность турецкого MASS была признана приемлемой. Достоверность шкалы была высокой ( $\alpha$ Кронбаха=0,89). Суммарные коэфффициенты корреляции для турецкого MASS варьировались от 0,53 до 0,70. Группы с низкими и высокими результатами сравнивались по показателю дискриминантной валидности. Все пункты значимо различались между студентами с низким и высоким уровнем успеваемости. Факторный анализ показал, что шкала имеет однофракторную структуру, которая объясняет $37,89 \%$ дисперсии. Коэффициент загрузки составлял от 0,56 до 0,73. Заключение. Исследование показало достоверность и предоставило доказательства валидности конструкции турецкой адаптированной версии MASS.

Ключевые слова: академическая самоэффективность, студенты-медики, разработка шкалы.

Для ссылки: Туран, С. Адаптация шкалы самоэффективности медицинских достижений (MASS) для Турции / С. Туран, М. Эльчин, А. Дересе // Вестник современной клинической медицины. - 2017. — Т. 10, вып. 2. C.53-57. DOI: 10.20969/VSKM.2017.10(2).53-57.

\section{Introduction}

Besides being medical experts, physicians are expected to be good communicators, managers, collaborators, patient advocates, scholars and professionals [1-3]. As those aptitudes are much harder to measure than the classic knowledge and skills, we developed a self-efficacy scale (Medical Achievement Self-efficacy Scale-MASS) in an earlier study that the students could judge their own capability to meet those expectations [4].

Self-efficacy is defined as «beliefs in one's own capabilities to organize and execute the courses of action required to produce given attainments» and as it is asserted - a mediator of behavioral change [5]. Many studies showed self-efficacy to be related with achievement [6-13]. Self-efficacy is expected to evolve over the study years as it is sensitive to changes in the personal context and becomes developed from educational experiences [14]. Therefore an evaluation of students' self-efficacy might reflect the impact of the entire medical curriculum.

In the earlier study, the MASS was studied with Flemish students enrolled in medical curricula [4]. Its content framework was based on the two most universal frameworks, the Five-star Doctor [1] and the CanMEDS roles $[2,3]$. The MASS was reported to have a high internal consistency reliability (Cronbach's $a=0,89$ ) [4]. The discriminant validity and predictive validity of the MASS were examined and it was shown that the MASS scores differed between lowly and highly achieving student groups, increased over the study years and predicted an acceptable proportion $(10 \%)$ of the variance in student performance on the Maastricht Progress Test [4].

In this study, our aim was to report the adaptation process of the MASS into Turkish, studying with medical students to initiate a broader study of medical curriculum innovations.

\section{Material and methods}

Instrument. The original MASS contained 18 items. It was rated on a five-point Likert scale. The scale score ranged from 18 to 90 , a higher score reflecting greater self-efficacy [4]. In the first step of the adaptation process, two experts translated the scale, and then two other experts back-translated it. Three experts checked whether the original statement and the translation had the same meaning. Native Turkish speakers (five-experts) also checked the translated version for meaningfulness of items. The original structure was preserved when translating into Turkish to ensure content validity.
Subjects. The study was conducted with undergraduate medical students at Hacettepe University $(n=547)$. Fifty percent $(50,1 \%)$ of the participants were female and almost sixty-five percent $(64,9 \%)$ of the participants were enrolled in the English stream of the medical curriculum (table 1).

Table 1

Percentages of gender, curriculum stream and grade of participants

\begin{tabular}{|l|c|c|}
\hline & Frequency & Percent \\
\hline Gender & 274 & \\
Female & 273 & 50,1 \\
Male & & 49,9 \\
\hline Curriculum stream & 355 & \\
English & 192 & 64,9 \\
Turkish & & 35,1 \\
\hline Year & 92 & \\
1 & 117 & 16,8 \\
2 & 108 & 21,4 \\
3 & 123 & 19,7 \\
4 & 61 & 22,5 \\
5 & 46 & 11,2 \\
6 & 547 & 8,4 \\
\hline Total & & 100,0 \\
\hline
\end{tabular}

Data Analysis. Cronbach's alpha was calculated for internal consistency reliability of the scale. Item-total correlation was calculated and the scores of lowly $(27 \%$ undermost) and highly performing groups (27\% upmost) were compared by means of a t-test. Exploratory factor analysis was conducted to determine the construct validity.

\section{Ethical Considerations}

Participation was voluntary. The instrument included a brief cover letter informing students about the purpose of the study. Students were asked to read and complete the informed consent form before answering the scale. The completed forms were anonymous.

\section{Results}

Content and face validity. During to the adaptation process of the MASS, we conformed to translation and back-translation procedure. The items of the MASS were based on the CanMEDS and the Five Stars Doctor. This structure was preserved when translating into Turkish to ensure content validity (table 2).

Item analysis and internal consistency reliability. Item-total correlation coefficients of the Turkish MASS ranged from 0,53 to 0,70 (table 3). The scores of lowly and highly performing groups scores were compared: 
Description of CanMEDS roles and items of MASS

\begin{tabular}{|c|c|c|c|}
\hline $\begin{array}{c}\text { CanMEDs } \\
\text { Roles }\end{array}$ & Description of CanMEDs Roles & Items & Items in Turkish scale \\
\hline Medical Expert & $\begin{array}{l}\text { As Medical Experts, physicians } \\
\text { integrate all of the roles, applying } \\
\text { medical knowledge, clinical skills, } \\
\text { and professional attitudes in their } \\
\text { provision of patient-centered care }\end{array}$ & $\begin{array}{l}\text { 1. I am able to perform the skills we } \\
\text { learned thus far on a patient. } \\
4 . \text { I am able to adequately apply the } \\
\text { subsequent steps of diagnosis and } \\
\text { treatment on a clinical problem. } \\
7 . \text { I have adequate knowledge of } \\
\text { basic medical sciences }\end{array}$ & $\begin{array}{l}\text { 1. Bu güne kadar öğrendiğim becer- } \\
\text { ileri bir hasta üzerinde uygulayabil- } \\
\text { irim. } \\
\text { 4. Klinik bir vakada uygun tanı ve } \\
\text { tedavi basamaklarını yeterli şekilde } \\
\text { uygulayabilirim. } \\
\text { 7. Temel tıp bilimlerinde yeterli bilgiye } \\
\text { sahibim }\end{array}$ \\
\hline Communicator & $\begin{array}{l}\text { As Communicators, physicians ef- } \\
\text { fectively facilitate the doctor-patient } \\
\text { relationship and the dynamic ex- } \\
\text { changes that occur before, during, } \\
\text { and after the medical encounter }\end{array}$ & $\begin{array}{l}\text { 5. I am able to react in a conflict } \\
\text { situation with a patient in a } \\
\text { communicatively adequate way. } \\
\text { 15. In a consultation I am able to } \\
\text { structure the information I obtain } \\
\text { from a patient }\end{array}$ & $\begin{array}{l}\text { 5. Bir fikir uyuşmazlığı durumunda } \\
\text { hastaya iletişim açısından yeterli } \\
\text { biçimde tepki verebilirim. } \\
\text { 15. Görüşme (konsültasyon) } \\
\text { sırasında hastadan aldığım bilgiyi } \\
\text { yapılandırabilirim. }\end{array}$ \\
\hline Collaborator & $\begin{array}{l}\text { As Collaborators, physicians } \\
\text { effectively work within a healthcare } \\
\text { team to achieve optimal patient } \\
\text { care }\end{array}$ & $\begin{array}{l}\text { 8. I am able to analyze a health } \\
\text { problem of a patient in a group. } \\
\text { 12. I feel able to collaborate on a } \\
\text { basis of equality with colleagues } \\
\text { from other health care disciplines }\end{array}$ & $\begin{array}{l}\text { 8. Bir hastanın sağlık sorununu grup } \\
\text { içinde analiz edebilirim. } \\
\text { 12. Diğer sağlık alanlarından olan } \\
\text { çalışma arkadaşlarımda eşit düzeyde } \\
\text { işbirliği yapabilirim }\end{array}$ \\
\hline Manager & $\begin{array}{l}\text { As Managers, physicians are } \\
\text { integral participants in healthcare } \\
\text { organizations, organizing } \\
\text { sustainable practices, making } \\
\text { decisions about allocating } \\
\text { resources, and contributing to the } \\
\text { effectiveness of the healthcare } \\
\text { system }\end{array}$ & $\begin{array}{l}\text { 16. I am able to make a cost- } \\
\text { effective choice when using } \\
\text { technical means for diagnosis or } \\
\text { therapy. } \\
\text { 18. I am able to deal with critical } \\
\text { incidents (unexpected, stressful } \\
\text { events) when providing health care }\end{array}$ & $\begin{array}{l}\text { 16. Tanı ve tedavi için teknik } \\
\text { cihazların kullanımında maliyet etkin } \\
\text { bir seçim yapabilirim. } \\
\text { 18. Sağlık hizmeti verirken kritik } \\
\text { durumlarla (beklenmedik, stresli } \\
\text { olaylarla) başa çıkabilirim }\end{array}$ \\
\hline $\begin{array}{l}\text { Health } \\
\text { Advocate }\end{array}$ & $\begin{array}{l}\text { As Health Advocates, physicians } \\
\text { responsibly use their expertise and } \\
\text { influence to advance the health and } \\
\text { well-being of individual patients, } \\
\text { communities, and populations }\end{array}$ & $\begin{array}{l}\text { 2. I have sufficient insight in the so- } \\
\text { cial factors that influence the health } \\
\text { problems of patients. } \\
\text { 14. I am able to handle a health prob- } \\
\text { lem in society preventatively }\end{array}$ & $\begin{array}{l}\text { 2. Hastaların sağlık problemlerini } \\
\text { etkileyen sosyal faktörler hakkında } \\
\text { yeterli görüşe sahibim. } \\
\text { 14. Toplumdaki bir sağlık sorununu } \\
\text { önleyici (koruyucu) şekilde ele } \\
\text { alabilirim }\end{array}$ \\
\hline Scholar & $\begin{array}{l}\text { As Scholars, physicians demon- } \\
\text { strate a lifelong commitment to } \\
\text { reflective learning, as well as the } \\
\text { creation, dissemination, application } \\
\text { and translation of medical knowl- } \\
\text { edge }\end{array}$ & $\begin{array}{l}\text { 3. I am able to search literature } \\
\text { relevant to a health problem elec- } \\
\text { tronically. } \\
6 . \text { I master the medical aspects that } \\
\text { have been dealt with in the Studium } \\
\text { generale or Medical Humanities (e.g. } \\
\text { philosophy, art, ...). } \\
9 . \text { I am able to write a sound scientific } \\
\text { paper on a health related subject. } \\
\text { 10. I am able to choose/to draw a } \\
\text { scientific set up for the solution of a } \\
\text { medical research problem }\end{array}$ & $\begin{array}{l}\text { 3. Bir sağlık sorunu ile ilgili tıbbi liter- } \\
\text { atürü elektronik olarak araştırabilirim. } \\
6 \text {. Tıp fakültesi programında yer alan } \\
\text { insan bilimlerinin (felsefe, sanat vb.) } \\
\text { bana sunduğu tıbbi görüşe sahibim. } \\
\text { 9. Bir sağlık konusu ile ilgili güvenilir } \\
\text { bilimsel bir makale yazabilirim. } \\
\text { 10. Tıbbi bir araştırma sorununun } \\
\text { çözümü için bilimsel araştırma } \\
\text { tasarımını seçebilirim }\end{array}$ \\
\hline Professional & $\begin{array}{l}\text { As Professionals, physicians } \\
\text { are committed to the health and } \\
\text { well-being of individuals and } \\
\text { society through ethical practice, } \\
\text { profession-led regulation, and high } \\
\text { personal standards of behaviour }\end{array}$ & $\begin{array}{l}\text { 11. I am able to take an underpinned } \\
\text { personal point of view related to the } \\
\text { ethical aspects when a patient asks } \\
\text { for euthanasia. } \\
\text { 13. I am able to handle my feelings of } \\
\text { anxiety when they appear in certain } \\
\text { clinical situations. } \\
\text { 17. I am able to recognize signs and } \\
\text { symptoms of burnout in my profes- } \\
\text { sional functioning }\end{array}$ & $\begin{array}{l}\text { 11. Bir hasta ötenazi istediğinde etik } \\
\text { açıdan desteklenen görüşlerimle bir } \\
\text { duruş ortaya koyabilirim. } \\
\text { 13. Belirli klinik durumlarda oluşan } \\
\text { endişe duygularımın üstesinden } \\
\text { gelebilirim. } \\
\text { 17. Profesyonel hayatımda } \\
\text { (işlevlerimde) tükenmişlik belirtilerini } \\
\text { ve işaretlerini tanıyabilirim }\end{array}$ \\
\hline
\end{tabular}

it was found that all items discriminated significantly $(p<0,001)$ (table 4$)$. The reliability of the scale was high (Cronbach's a=0,89).

Discriminant validity. Lower and upper score groups were compared as an indicator of discriminant validity. All items discriminated significantly between lowly and highly performing students $(p<0,001)$ (table 4).

\section{Construct of the scale}

Explatory factor analysis was used to obtain information about the structure of the scale. The KaiserMeyer-Olkin coefficient (KMO) was 0,92 and Bartlett's test reached statistical significance $(p<0,001)$.

Factor analysis produced three factors. All items loaded on one factor, that explained $37,89 \%$ of the variance. Factor loadings ranged from 0,51 to 0,72 . 
T a b le 3 The high loads and the high percentage of explained Item-Total Statistics of MASS

\begin{tabular}{|c|c|c|}
\hline \multirow{2}{*}{$\begin{array}{c}\text { Item } \\
\text { number }\end{array}$} & $\begin{array}{c}\text { Original study }(n=1060) \\
\text { (Turan et al., 2013) }\end{array}$ & $\begin{array}{c}\text { Turkish students } \\
(n=547)\end{array}$ \\
\cline { 2 - 3 } & Item-Total Correlation & Item-Total Correlation \\
\hline 1 & 0,40 & 0,53 \\
\hline 2 & 0,52 & 0,56 \\
\hline 3 & 0,41 & 0,53 \\
\hline 4 & 0,63 & 0,66 \\
\hline 5 & 0,57 & 0,59 \\
\hline 6 & 0,39 & 0,55 \\
\hline 7 & 0,56 & 0,59 \\
\hline 8 & 0,64 & 0,69 \\
\hline 9 & 0,55 & 0,57 \\
\hline 10 & 0,60 & 0,66 \\
\hline 11 & 0,45 & 0,53 \\
\hline 12 & 0,43 & 0,62 \\
\hline 13 & 0,49 & 0,65 \\
\hline 14 & 0,63 & 0,70 \\
\hline 15 & 0,61 & 0,69 \\
\hline 16 & 0,57 & 0,60 \\
\hline 17 & 0,51 & 0,63 \\
\hline 18 & 0,58 & 0,67 \\
\hline
\end{tabular}

The comparison of lower and upper score groups

Table 4 of MASS

\begin{tabular}{|c|c|c|c|c|c|c|}
\hline \multirow{2}{*}{$\begin{array}{c}\text { Item } \\
\text { number }\end{array}$} & \multicolumn{2}{|c|}{ Lower Group } & \multicolumn{2}{|c|}{ Upper Group } & \multirow{2}{*}{ t-value } & $p<$ \\
\cline { 2 - 5 } & Mean & SS & Mean & SS & & \\
\hline 1 & 3,11 & 0,92 & 4,25 & 0,78 & $-11,35$ & 0,001 \\
\hline 2 & 3,16 & 0,81 & 4,31 & 0,67 & $-12,99$ & 0,001 \\
\hline 3 & 3,43 & 0,91 & 4,51 & 0,64 & $-11,56$ & 0,001 \\
\hline 4 & 2,84 & 0,83 & 4,24 & 0,74 & $-15,19$ & 0,001 \\
\hline 5 & 3,48 & 0,86 & 4,67 & 0,54 & $-14,03$ & 0,001 \\
\hline 6 & 2,87 & 1,02 & 4,21 & 0,95 & $-11,69$ & 0,001 \\
\hline 7 & 2,81 & 0,89 & 4,19 & 0,69 & $-14,71$ & 0,001 \\
\hline 8 & 3,15 & 0,74 & 4,46 & 0,58 & $-16,85$ & 0,001 \\
\hline 9 & 1,92 & 0,91 & 3,66 & 0,99 & $-15,61$ & 0,001 \\
\hline 10 & 2,65 & 0,83 & 4,15 & 0,73 & $-16,30$ & 0,001 \\
\hline 11 & 3,13 & 1,03 & 4,33 & 0,73 & $-11,41$ & 0,001 \\
\hline 12 & 3,69 & 0,91 & 4,80 & 0,42 & $-13,19$ & 0,001 \\
\hline 13 & 3,15 & 0,88 & 4,50 & 0,62 & $-15,09$ & 0,001 \\
\hline 14 & 3,13 & 0,82 & 4,58 & 0,60 & $-17,08$ & 0,001 \\
\hline 15 & 3,47 & 0,82 & 4,72 & 0,45 & $-15,84$ & 0,001 \\
\hline 16 & 2,81 & 1,04 & 4,22 & 0,73 & $-13,31$ & 0,001 \\
\hline 17 & 3,09 & 0,96 & 4,46 & 0,60 & $-14,41$ & 0,001 \\
\hline 18 & 2,95 & 0,96 & 4,54 & 0,57 & $-16,89$ & 0,001 \\
\hline
\end{tabular}
variance on one factor showed that all items of the instrument indicated the same dimension (table 5).

Table 5

Summary of Exploratory Factor Analysis Results

\begin{tabular}{|l|c|c|c|c|}
\hline \multirow{2}{*}{ Item } & \multirow{2}{*}{$\begin{array}{c}\text { Commu- } \\
\text { nalities }\end{array}$} & \multicolumn{3}{|c|}{ Component } \\
\cline { 3 - 5 } & 0,421 & 0,722 & $-0,253$ & $-0,036$ \\
\hline Item 14 & 0,43 & $-0,156$ \\
\hline Item 15 & 0,561 & 0,714 & $-0,213$ & 0,003 \\
\hline Item 8 & 0,365 & 0,697 & 0,227 & $-0,215$ \\
\hline Item 18 & 0,536 & 0,691 & $-0,322$ & 0,020 \\
\hline Item 13 & 0,509 & 0,666 & $-0,378$ & 0,001 \\
\hline Item 4 & 0,305 & 0,661 & 0,315 & $-0,131$ \\
\hline Item 10 & 0,556 & 0,651 & 0,218 & 0,281 \\
\hline Item 12 & 0,537 & 0,638 & $-0,330$ & $-0,270$ \\
\hline Item 17 & 0,532 & 0,629 & $-0,200$ & 0,356 \\
\hline Item 5 & 0,489 & 0,602 & $-0,142$ & $-0,448$ \\
\hline Item 16 & 0,470 & 0,593 & $-0,214$ & $-0,133$ \\
\hline Item 7 & 0,595 & 0,570 & 0,463 & 0,432 \\
\hline Item 2 & 0,587 & 0,560 & 0,246 & $-0,319$ \\
\hline Item 9 & 0,586 & 0,534 & 0,381 & 0,087 \\
\hline Item 1 & 0,580 & 0,530 & 0,365 & 0,161 \\
\hline Item 3 & 0,598 & 0,519 & 0,265 & 0,358 \\
\hline Item 11 & 0,509 & 0,515 & $-0,277$ & 0,169 \\
\hline Item 6 & 0,627 & 0,515 & 0,108 & 5,916 \\
\hline \% of Total & & 37,886 & 8,221 & \\
\hline Variance Explained & & & \\
\hline
\end{tabular}

Extraction Method: Principal Component Analysis.

\section{Discussion and Conclusion}

Validity refers to the degree to which the scale measures what it claims to measure [15]. Since items of the MASS were based on the CanMEDS and the Five Stars Doctor [4], and this structure was preserved during translation, Turkish MASS has a good content validity.

The Turkish MASS showed a high internal consistency reliability. The high item-total correlation coefficients of all items of the MASS revealed that they measured the same general construct. In the earlier study with Flemish students, the original MASS had also a good reliability value [4].

The significant difference of means of lowly and highly achieving student groups indicated the discriminant validity of the scale. The construct of the scale was investigated: it was found that the MASS has one dimension.

Our study has some limitations. Further studies are needed to provide evidence of the reliability and validity of the MASS. The study was conducted on medical students enrolled in an integrated medical curriculum. The MASS should be further tested in schools with other types of medical curricula. Internal consistency of the MASS should be examined with test-retest correlation.

Despite these limitations, this study reveals that the Turkish MASS has a good relaibility. It has a one- 
dimension structure and a good content validity since it has been developed based on a universal medical competency framework.

Transparency of the study. The study did not have sponsorship. The authors are solely responsible for the provision of the final version of the manuscript for publication.

Declaration of financial or other relationships. All authors participated in the conception and design of the study and in the writing of the manuscript. The final version of the manuscript was approved by all the authors. The authors did not receive a fee for the study.

\section{REFERENCES}

1. Boelen C. The Five-star Doctor: an asset to health care reform? Genava: World Health Organization. 1997: http:// www.who.int/hrh/en/HRDJ_1_1_02.pdf

2. Frank JR ed. The CanMEDS $\mathbf{2 0 0 5}$ physician competency framework; Better standards. Better physicians; Better care. Ottawa: The Royal College of Physicians and Surgeons of Canada. 2005; 40 p.

3. Frank JR, Danoff D. The CanMEDS initiative: implementing an outcomes-based framework of physician competencies. Medical Teacher. 2007; 29: 642-647.

4. Turan S, Valcke M, De Maeseneer J, Aper L, Koole S, De Wispelaere C, Deketelaere A, Derese A. A novel Medical Achievement Self-efficacy Scale (MASS): A valid and reliable tool. Medical Teacher. 2013; 35 (7): 575-580.

5. Bandura A. Self-efficacy: The exercise of control. New York: Freeman. 1997; 604 p.

6. Allen R, Heard J, Savidge M, Bittengle J, Cantrell M, Huffmaster T. Surveying students' attitudes during the
OSCE. Advances in Health Sciences Education. 1998; 3: 197-206.

7. Tresolini CP, Stritter FT. An analysis of learning experiences contributing to medical students' self-efficacy in conducting patient education for health promotion. Teaching and Learning in Medicine: An International Journal. 1994; 6 (4): $247-254$

8. Mann KV, Lindsay EA, Putnam RW, Davis DA. Increasing physician involvement in cholesterol-lowering practices: the role of knowledge, attitudes and perceptions. Advances in Health Sciences Education. 1997; 2: 237-253.

9. Kaufman DM, Laidlaw TA, Langille D, Sargeant J, MacLeod H. Differences in medical students' attitudes and self-efficacy regarding patient-doctor communication. Academic Medicine. 2001; 76 (2): 188.

10. Mavis B. Self-Efficacy and OSCE performance among second year medical students. Advances in Health Sciences Education. 2001; 6: 93-102.

11. Johnston M, O'Carroll R, Hart J, McGee HM. Experiencing the evidence' in behavioural sciences increases selfefficacy. Medical Education. 2004; 38: 563-564.

12. Katz S, Feigenbaum A, Pasternak S, Vinker S. An interactive course to enhance self-efficacy of family practitioners to treat obesity. BMC Medical Education. 2005; 5: 4.

13. Wright SW, Lindsell CJ, Hinckley WR, Williams A, Holland C, Lewis $\mathrm{CH}$, Heimburger $\mathrm{G}$. High fidelity medical simulation in the difficult environment of a helicopter: feasibility, self-efficacy and cost. BMC Medical Education. 2006; 6: 49 .

14. Bandura A. Encyclopedia of human behavior. New York: Academic Press. 1994; 4: 71-81.

15. Fraenkel JR, Wallen NE. Valididity and reliability. How to design and research in education. New York: McGraw-Hill, INC. 1996; 3: 153-171. 